\title{
Adaptations for Teaching Children with Special Educational Needs in ESL Context
}

\author{
Martha Elena Alonzo Rezabala ${ }^{1} \&$ Jhonny Saulo Villafuerte Holguín ${ }^{2}$ \\ ${ }^{1}$ Student of the Program PINE, Universidad Laica Eloy Alfaro de Manabí, Manta, Ecuador \\ ${ }^{2}$ Professor of the Program PINE, Universidad Laica Eloy Alfaro de Manabí, Manta, Ecuador \\ Correspondence: Jhonny Saulo Villafuerte Holguín, Facultad Ciencias de la Educaciòn, Universidad Laica Eloy Alfaro \\ de Manabí, Via Manta-San Mateo, Ecuador.
}

Received: November 21, 2019

Accepted: December 5, 2019 Available online: December 30, 2019

doi:10.11114/ijsss.v8i1.4668

URL: https://doi.org/10.11114/ijsss.v8i1.4668

\begin{abstract}
Public policy for inclusive education in Ecuador favors the entry of students with Special Education Needs into conventional schools. However, teachers require to develop adaptations to improve their work with students who have such conditions. This research aims to study the contribution of audiovisuals in adaptations and modifications for teaching English Language to a child reported with attention-deficit. This case of study refers to a boy attending the 4th Grade of elementary school in Manta-Ecuador. The research team designed a 10-sessions educational intervention for stimulating the child attention and improving his communication skills in English as a foreign language. A mixture of qualitative and quantitative research methodologies is applied to determine the participant's English language skills evolution. This work also introduces teaching strategies that convine games and technology to support the vocabulary acquisition process of children with physical or intellectual disabilities. Results show how the videos catch and keep the participant's attention during more time; and how the voice self-recording supports his listening and speaking practice. Such circumstance opens multiple possibilities to innovate the current adaptations and modifications for improving the teaching and learning process of children with special educational needs in ESL context.
\end{abstract}

Keywords: English language teaching, inclusive education, educational technology, curriculum adaptations, special educational needs

\section{Introduction}

\subsection{The Problem to Research}

Educational technology had reached heterogeneous levels of development around the world because, government policies, socio-economic development plans, and people's access to information and communication technologies (ICT). Nevertheless, Garay, Luján and Etxebarria (2013) affirm the construction of learning environments using technologies tries to become a less protagonist in its condition of a means, instead of the purpose of the educational process. However, Chavez, Pizarro and Jimenez (2018) argue that, the usage of technology for teaching English as a Foreign Language (EFL) to students with attention-deficit is still scarce and high required in Ecuador.

The articulation between the Scholar Curriculums (SC) and the Information and Communication Technologies (ICT) can attract learner sense toward the digital learning environments. Thus, the expectation is to offer education of quality to students of different ages, abilities, individual or group limitations, and multicultural contexts.

The usage of ICT is frequent in diverse educational events, such as the introduction of new content, educational management activities, inclusive education, and professional training (Fernández and Torres, 2015; Salgado, 2017; Villafuerte and Benítez, 2018).

Besides, government policies for inclusive education in Ecuador have evolved positively in recent years. However, for achieving equitable, fair and, progressive societies, it is required to develop adaptations for working with students under vulnerable conditions. Thus, Luzardo, Villafuerte, Bravo, and Romero (2018) agree on the need to move towards inclusive educational practices and the strengthening of the inclusive culture in Ecuador.

Educational technology, learning environments and Audiovisual media 
To Zourou (2007), ICT helps teachers to structure and manage learner's cognitive mechanisms. Thus, educational technology integrates the advances of different fields of knowledge such as microelectronics, information technology, telecommunications, and software development (Garay, 2012) having as the main idea, to articulate the school curriculum to ICT for creating new innovative and inclusive learning environments (Villafuerte, 2019).

In the American context, Heath and Ravitz (2001) argue that researchers improved the constructivist learning environments in recent years, supported in educational technology, however it was necessary looking for new alternative didactics for training the teaching staff. In the European context, Castaño (2003), and Salinas (2011) warn about the need to review teachers' knowledge regarding their usage of educational technology, teaching and learning strategies, and the material online distribution.

Studies executed in Asia sustain the introduction of ICT in universities has affected student health, generating high anxiety when they work extensively in front of a computer (Ahmad, 2011; and Sun, Tsai, Finger, Chen, and Yeh, 2007). The given scenarios confirm teacher's and students` necessity to develop technical and cognitive skills to solve problems arising in the usage of digital environments (Aviram and Eshet-Alkalai, 2006).

However, Adell and Castañeda (2010) argue, there are three types of tools, sites, and activities used for innovating learning environments: (a) reading the information sources, (b) reflecting the information, and (c) exchange the information.

In those learning environments, it is necessary to evaluate learners' progress and their critical thinking capacity (Valqui, González, Góngora, and Bazán, 2015), avoiding those obsolete teaching strategies still repeated through virtual spaces (Ricoy and Couto, 2012).

Thus, considering diverse learners age, learning achievements, and inclusion conditions, teachers and students of a foreign language must carry out activities to discover information, repeat words, produce texts and audios, comprehend reading for selecting, filtering, reflecting and reconstructing the new knowledge (Cabero and Barroso 2016; Esteve, Duch and Gisbert, 2014; Garay et al., 2013). Therefore, educational services set achieving higher levels of efficiency through the usage of tools provided by ICT (Palazio-Arko, 2016).

Audiovisual media is also known as communication information technology (ICT). It is part of the didactic resources called multisensory whose purpose is approaching students to a more dynamic training process and allowing learners' proximity to the reality of the object of study (Barros and Barros, 2015). Thus, technology innovations provide teachers the necessary information for daily use (Chavez et al., 2018).

Among previous studies, Hernández and Fuentes (2011) maintain that it persists the need to provide users with search strategies and selection of information on the Internet. Adell and Castañeda (2010) argue that learning environments are tools that contribute positively to the innovative teaching-learning processes in the current education system.

\subsection{Inclusive Education and Curricular Adaptations}

The Inclusive Education (IE) takes care of individuals who have anyone or some of the following disabilities: deafness, blindness, various types of paralysis, and other neuromotor problems as intellectual impairment, or emotional learning problems (Klingler, 2000).

Some of the behavioral disorders observed in students with Special Educational Needs (SEN) are related to attention-deficit or impulsivity. In other cases, students can not follow instructions (Medina, 2010). A special education need refers to the people's alteration of the attention function (Narvarte, 2007). This condition could reduce a student's capability to follow the same learning speed to the rest of the pupils in a class. However, the common learner's reaction is maladaptive and incoherent about the learners' level of development (Hidalgo and Zoutullo, 2014).

The adaptation consists of the curriculum adjustment or modification according to student needs, and the goals set forth by the student's Individualized Education Program (IEP). To Hall, Ge Vue, Koga, and Silva (2004), the concept should break down broadly into curriculum modification and curriculum enhancement. The adaptations are modifications in the elements of the curriculum, such as the objectives, skills, methodology, resources, activity, time of the accomplishment of the task, evaluation, as well as the conditions of access to respond to each student's special educational needs (Arguello, 2013).

\section{Method}

This work applies a mixture of qualitative and quantitative research approaches. The pretest determines the participant's communication skill level found before the educational intervention. The postest demonstrates the student's progress in a qualification that serves for his school report.

The educational intervention design follows the psycho and educational principles of inclusive education. Also, it applies Fernandez, Hinojo, and Aznar's (2003) experience for inclusive education. 
The educational intervention consists of 10 sessions and the process is executed within the school environment where the child attends regularly following the guidelines of Arguello (2013) and Medina (2010).

These adaptations correspond with the objective of the present research that consists of the implementation of audiovisuals for teaching English to children with Special Educational Needs. The questions to answer in this work are:

1. How the audiovisual can be used in curricular adaptations for English language teaching?

2. What kind of evaluation can be adapted to work with children with special educational needs in English class?

3. How was the evolution of the learner's communication skills in English when the audiovisuals are used in curricular adaptations?

\subsection{The Participant: The Case of Study}

This case of study is about an-8-years-old student, sex male. He attends the fourth-grade, in an elementary private school in Manta, Ecuador.

This process began in September 2018 and finished in February 2019. For the protection of his identity, he is called "Angel" in this research.

Angel is the second son of a family of three kids. His family belongs to the middle socioeconomic level. His mother is 38-year-old, and his father is 40-years-old. Angel presents an overactive behavior during his time in school.

According to the Student Counseling report, the child corresponds to the group of students with special educational needs, described in the official Work Guide of the Ecuadorian Ministry of Education: Curricular Adaptations for Special and Inclusive Education (Arguello, 2013).

Angel presents attention-deficit, dominant behavior, and resistance to authority. These conditions reflect his non-participation in recreational and socio-educational activities. He also avoids sharing time with his classmates.

In the specific class: English as a Foreign Language, he reports a delay to the class average. Angel is very participatory at home, but he always requires help to carry out his school assignments.

\subsection{Instruments}

\subsubsection{The Instruments Used in This Work Are}

Lesson Plan format: For designing each lesson curricular adaptation, the lesson plan format of the Ministry of Education of Ecuador was used. This instrument includes the elements: General information; Learning Skills, Topic; Curricular adaptations; Evaluation procedure; Class goal; and Resources.

The research process through the implementation of the curricular adaptations in location was developed for 5 weeks subdivided into two sessions per week with a total of 20 hours of 45 minutes classes organized in 10 sessions.

\subsubsection{Observation Register}

The instrument used to register the execution of each session consisted in 2 aspects: (1) Achievement; and (2) Notes to consider. The observation register is added at the end of each lesson planning sheet. Researcher added the progress, difficulties and notes for future replays.

Besides, voices of teachers were collected and exposed in the discussion section to ratify the contribution of Audivisials in the adaptations and modification process of the National English as a Foreign Language curriculum.

\subsubsection{Evaluation Rubric}

This instrument was designed for the research team to evaluate the learner progress of the four skills of communication in English as a foreign language. The categories of achievement used are Excellent, good, Satisfactory, and weak. Each category describes the levels and characteristics that the student is expected to reach.

\subsubsection{Registers of the Participant English Communication Skills Evolution}

It is a descriptive register that contrast the learner performance at the beginning of the intervention from the beginning to the end of the process. The information is analized since qualitative and quantitative approaches. A figure also is included to show the participant communication skills evolution.

\subsection{Researching Plan}

a. Constructing theoretical and analysis criteria: interviews were conducted with two teachers of special education from the Universidad Laica Eloy Alfaro de Manabí, professors of the English language area, psychologist of the institution where the intervention was performed.

b. English language knowledge diagnostic session: This stage allows determining the informant English knowledge 
level.

c. Curricular adaptation design. It was used the audiovisual for teaching English language vocabulary and sentences of level beginner, according to the English as Foreign Language National curriculum.

d. Empiric stage: Curricular adaptations execution during 10 sessions including pretest and postest.

e. Interview to professionals of inclusion: The instrument of interview was applied to obtain information about the pertinence of the educational intervention proposed. The professional recommendations were applied in educational intervention design.

f. Analysis and contrasting of results. The information obtained in the empiric stage was analyzed using qualitative and quantitative research approaches.

\subsection{Ethic Norms}

This research applies the following ethic principles:

1. The participant's relatives or tutor had signed a concern letter and declared they participated voluntarily in this research.

2. The participant full is kept in anonymous to protect his identity.

3. The data collected in this work will be managed by the authors for 7 years.

4. This research information can be used only for academic purposes. It will not be commerce for any reason.

\section{Results}

To answer the question 1: How the audiovisual can be used in curricular adaptations for English language teaching? See table 1 .

Table 1. Audiovisuals adaptations teaching English language to children with Attention-deficit

\section{General information}

School grade: fourth grade of elementary school.

Ecuadorian curricular axis: communication and cultural awareness, oral communication, reading, writing, language through the arts.

Learning axis: speaking, reading, writing, listening, text and literature in English as second language.

Objective: Learner can identify and descrive vocabulary regularly used in everyday life.

\section{Session 1}

\begin{tabular}{|c|c|c|c|}
\hline Learning Skills & Topic & Curricular adaptations & Evaluation \\
\hline \multirow[t]{2}{*}{$\begin{array}{l}\text { Speaking and } \\
\text { reading. }\end{array}$} & $\begin{array}{l}\text { Demonstrative } \\
\text { pronouns. } \\
\text { Introduction } \quad \text { to } \\
\text { singular } \quad \text { and }\end{array}$ & \multirow{4}{*}{$\begin{array}{l}\text {-Teach the concepts of near and far. } \\
\text {-Show a video about singular and } \\
\text { plural objects. } \\
\text {-Ask the student some questions } \\
\text { about near and far using objects in } \\
\text { the classroom. } \\
\text {-Ask the student some questions } \\
\text { about singular and plural objects. } \\
\text { - Record the child's voice while } \\
\text { reading the sentences presented. } \\
\text {-Interact with the child while } \\
\text { listening to his own recording. } \\
\text {-Introduce the reading "my animals" } \\
\text {-Introduce the reading purpose. } \\
\text {-According to the image of the } \\
\text { reading, place the corresponding } \\
\text { arrows near and far from the farmer. }\end{array}$} & \multirow{4}{*}{$\begin{array}{l}\text { In the reading, place the } \\
\text { demonstrative pronouns of the } \\
\text { indicated color } \\
\text { Recognize the vocabulary of } \\
\text { reading by placing the } \\
\text { corresponding sound while } \\
\text { reading the statement }\end{array}$} \\
\hline & & & \\
\hline \multicolumn{2}{|l|}{ Class goal: } & & \\
\hline $\begin{array}{l}\text { To identify the } \\
\text { demonstrative pronouns } \\
\text { the objective and its } \\
\text { functions }\end{array}$ & $\begin{array}{l}\text { Tablet, } \\
\text { Internet } \\
\text { connection, } \\
\text { Speakers, Videos }\end{array}$ & & \\
\hline \multicolumn{4}{|l|}{ Observation report 1} \\
\hline \multicolumn{4}{|c|}{$\begin{array}{l}\text { Achievement: To recognize demonstrative pronouns. } \\
\text { To identify the demonstrative pronouns in the images. } \\
\text { To use phrases with demonstrative pronouns }\end{array}$} \\
\hline \multicolumn{4}{|c|}{$\begin{array}{l}\text { Observations In classes, Angel showed distracted, he did not give the importance to the activities introduced. } \\
\text { When he recorded his own voice and listened, it was noticed that he was interested in how this activity worked. His } \\
\text { attention was focused, and his hyperactivity decreased. }\end{array}$} \\
\hline
\end{tabular}




\section{Session 2}

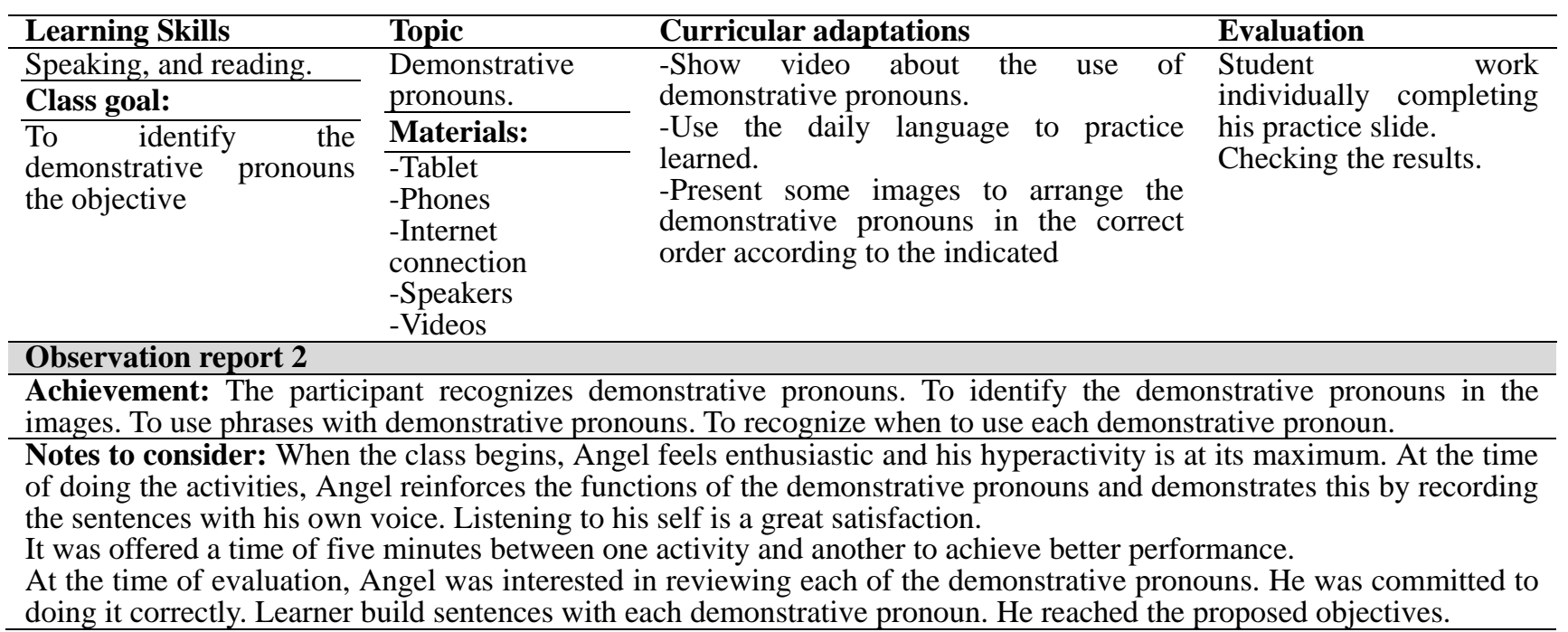

Session 3

\begin{tabular}{|c|c|c|c|}
\hline Learning Skills & Topic & Curricular adaptations & Evaluation \\
\hline \multirow[t]{5}{*}{$\begin{array}{l}\text { Speaking, reading, and } \\
\text { listening. }\end{array}$} & $\begin{array}{l}\text { Personal pronouns and } \\
\text { possessive adjectives. }\end{array}$ & \multirow{7}{*}{$\begin{array}{l}\text {-Show video about personal } \\
\text { pronouns } \\
\text {-Present some images to } \\
\text { strengthen personal pronouns. } \\
\text {-Show video about the topic. } \\
\text {-Show the concordance between } \\
\text { personal pronouns and possessive } \\
\text { adjectives. } \\
\text {-Show slides of possessive } \\
\text { adjectives for singular and plural } \\
\text { personal pronouns. } \\
\text {-Introduce new vocabulary. }\end{array}$} & \multirow{7}{*}{$\begin{array}{l}\text { Complete the sentences. } \\
\text { Play the audios and } \\
\text { arrange the figures as } \\
\text { appropriate. } \\
\text { Check the results. }\end{array}$} \\
\hline & & & \\
\hline & Materials: & & \\
\hline & Computer & & \\
\hline & Phones (Internet) & & \\
\hline \multirow[b]{2}{*}{$\begin{array}{l}\text { Use possessive adjectives } \\
\text { to express who owns } \\
\text { something }\end{array}$} & Videos & & \\
\hline & & & \\
\hline \multicolumn{4}{|l|}{ Observation report 3} \\
\hline \multicolumn{4}{|c|}{$\begin{array}{l}\text { Learning achievements: Concordance of personal pronouns with possessive adjectives. } \\
\text { To recognize differences between the possessive adjectives singular and plural. } \\
\text { To use the vocabulary given in sentences. }\end{array}$} \\
\hline \multicolumn{4}{|c|}{$\begin{array}{l}\text { Observations: In class, Angel understands the difference between singular and plural. } \\
\text { The singular and the plural were practiced through the repetition of each personal pronoun and the difference in terms } \\
\text { of gender. Videos shown to Angel they are fun and fulfill the function of pointing out the possessive adjectives. The } \\
\text { child wants to repeat the videos and comments on the characters. He listened to the sentences in the audio given and } \\
\text { must organized with the possessive adjectives offered as a keyword. }\end{array}$} \\
\hline
\end{tabular}

Session 4

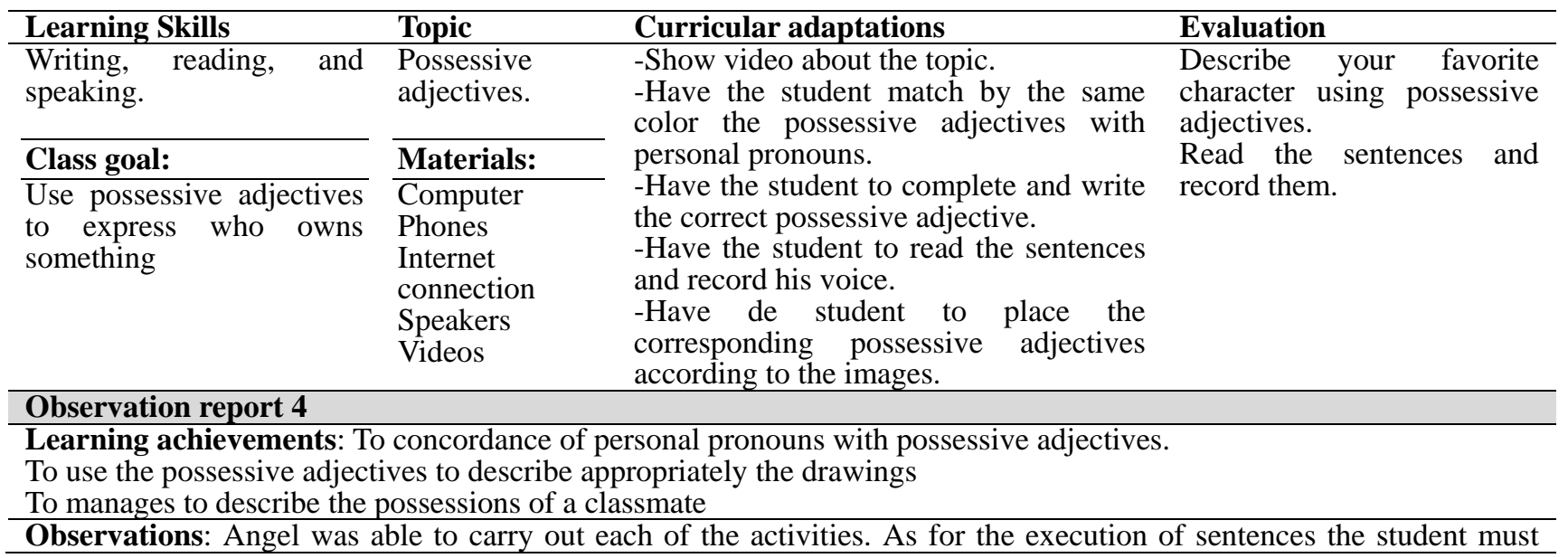


relate according to the personal pronouns to their respective possessive adjectives. The child understands the function of owning and belonging. The use of video makes the learning process much more entertaining. A break of 3 to 6 minutes of interval is offered between two to three activities, depending on the complexity in carrying them out. When Angel records and plays his own voice with the indicated answers is happy. He is very interested in pronouncing correctly.

Session 5

\begin{tabular}{|c|c|c|c|}
\hline Learning Skills & Topic & Curricular adaptations & \multirow{3}{*}{$\begin{array}{l}\text { Evaluation } \\
\text { Fill in the blank with the right } \\
\text { comparative adjectives the } \\
\text { sentences to have the right } \\
\text { meaning. } \\
\text { Read the sentences and earn a } \\
\text { star. }\end{array}$} \\
\hline Reading, and writing. & $\begin{array}{l}\text { Comparative } \\
\text { adjectives. } \\
\text { Vocabulary }\end{array}$ & \multirow{2}{*}{$\begin{array}{l}\text {-Show video and images about } \\
\text { transports. } \\
\text {-The student place the sound of the } \\
\text { transport as appropriate. } \\
\text {-Ask the student to link with lines } \\
\text { the image with the correct name of } \\
\text { transportation and repeat it. } \\
\text {-Show transports names according } \\
\text { to where they operate. (water, land, } \\
\text { air) } \\
\text {-Show video about comparative } \\
\text { adjectives rules. } \\
\text {-Introduce the comparatives } \\
\text { adjectives rules chart. } \\
\text {-Student records his voice while is } \\
\text { repeating the } \\
\text { transportation. } \\
\text {-Ask the student to put in color red } \\
\text { the right comparative adiective } \\
\text { according to the sentences }\end{array}$} & \\
\hline $\begin{array}{l}\text { Use comparative } \\
\text { adjectives to compare two } \\
\text { people, animals or things. }\end{array}$ & $\begin{array}{l}\text { Materials: } \\
\text { Computer } \\
\text { Phones } \\
\text { Internet } \\
\text { connection } \\
\text { Speakers } \\
\text { Videos }\end{array}$ & & \\
\hline
\end{tabular}

Learning achievements: To Recognize the utility of each transportation words.

To recognize the function of the comparative adjectives

To understand, differentiate and apply the comparative rule.

To Learn how and where to add -er to the end of most one-syllable adjectives to form the comparative.* If the adjective ends in -e, add -r. Learnt why in two-syllable adjectives are used with either -er or more or less to form the comparative form.

Observations: Angel relates the image of transportation with the corresponding sound imitating its sound, strengthening his knowledge.

He records each word and places it in the image correctly. The child has fun during the activity and wants to repeat it. The student is totally focused on the activity, he does not need time to rest between activities. His hyperactivity is reduced; he does not make excuses wanting to get up constantly.

\section{Session 6}

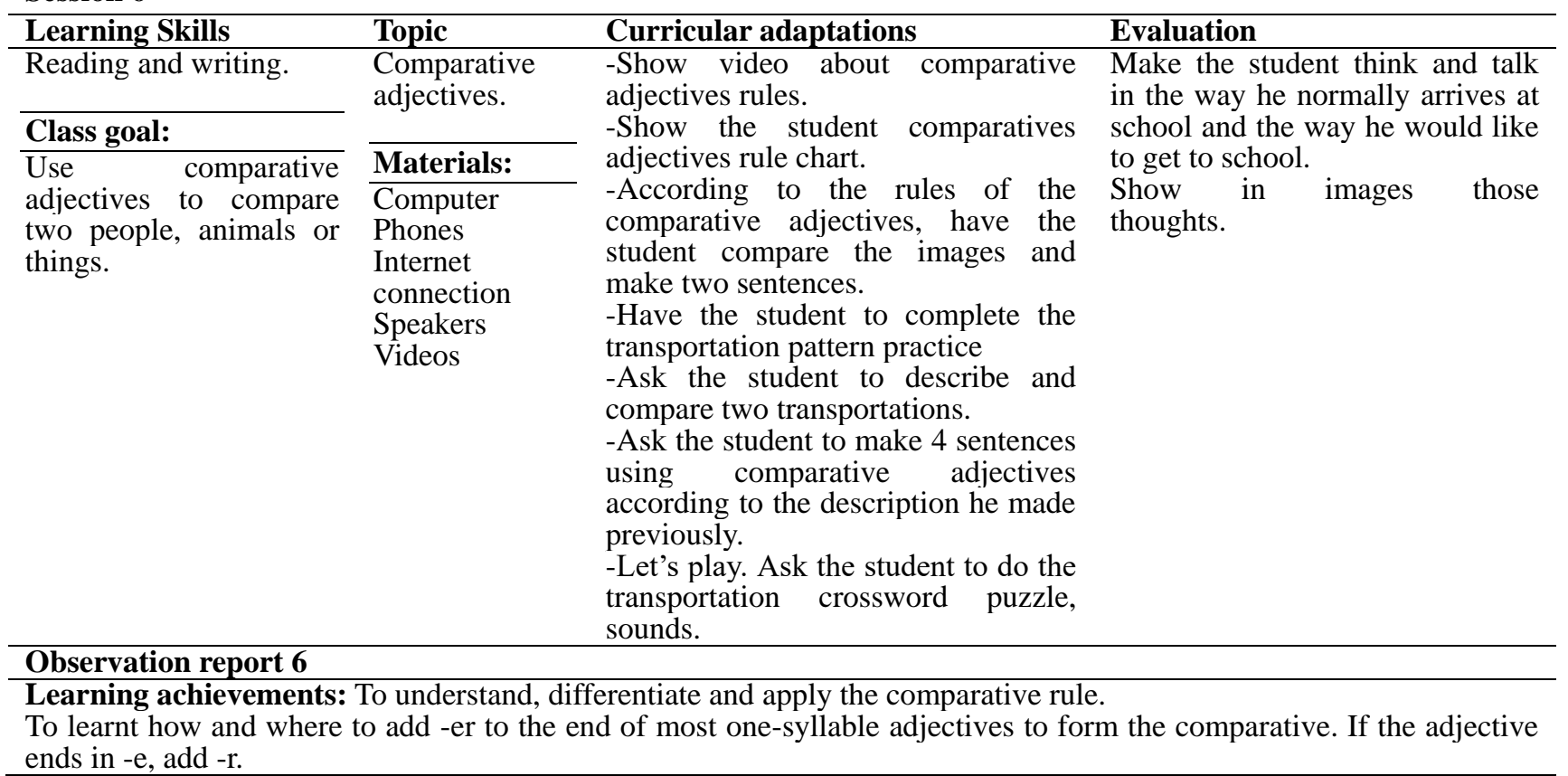


To Learn why in two-syllable adjectives are used with either -er or to form the comparative.

Observations: The class began with the observation of a video which taught transports and comparative adjectives. Angel works and practices with the Transportation pattern recognizing the names of the transports by placing them in the correct order. Thanks to activities such as the puzzle, the child relates the writing of the transport's names. His attention was to the maximum level, although it cost him a lot to understand the dynamics of the activity since it was the first time in realizing it. He needed five minutes of recess and returned to the activity.

\section{Session 7}

\section{Learning Skills \\ Reading. and \\ Writing.}

\section{Class goal:}

Acquire the structures of the possessive adjectives

\begin{tabular}{l} 
Topic \\
Possessive \\
adjectives \\
\hline
\end{tabular}

Materials:

Computer

Phones

Internet

connection

Speakers

Videos

\begin{abstract}
Curricular adaptations
-Show a video introducing the new vocabulary.

-Ask the student to link images with the right word.

-Ask the student to record his own voice while listing the name of the objects.

-Show a video of clothing song.

-Use the daily language to practice the vocabulary.

-Allow the student to make a difference of what belongs to a girl or a boy according to the request.

-Introduce a game to play using the new vocabulary.
\end{abstract}

\section{Evaluation \\ Perform the image puzzle using the right clothes. \\ Describe each of them.}

\footnotetext{
Observation report 7

Learning achievements: To recognize the utility of each transportation words.

To recognize the function of the comparative adjectives

To understand, differentiate and apply the comparative rule.

To learn how and where to add -er to the end of most one-syllable adjectives to form the comparative.* If the adjective ends in -e, add -r. To Learn why in two-syllables adjectives are used with either -er or more or less to form the comparative

The possessive adjectives are identified for the learner.

Observations: The sequence of each activity is carried out enthusiastically. Handles every detail of the slides very well on its own. He Asked occasional questions about shapes and colors or the meaning of some new words he felt curiousity.
}

\section{Session 8}

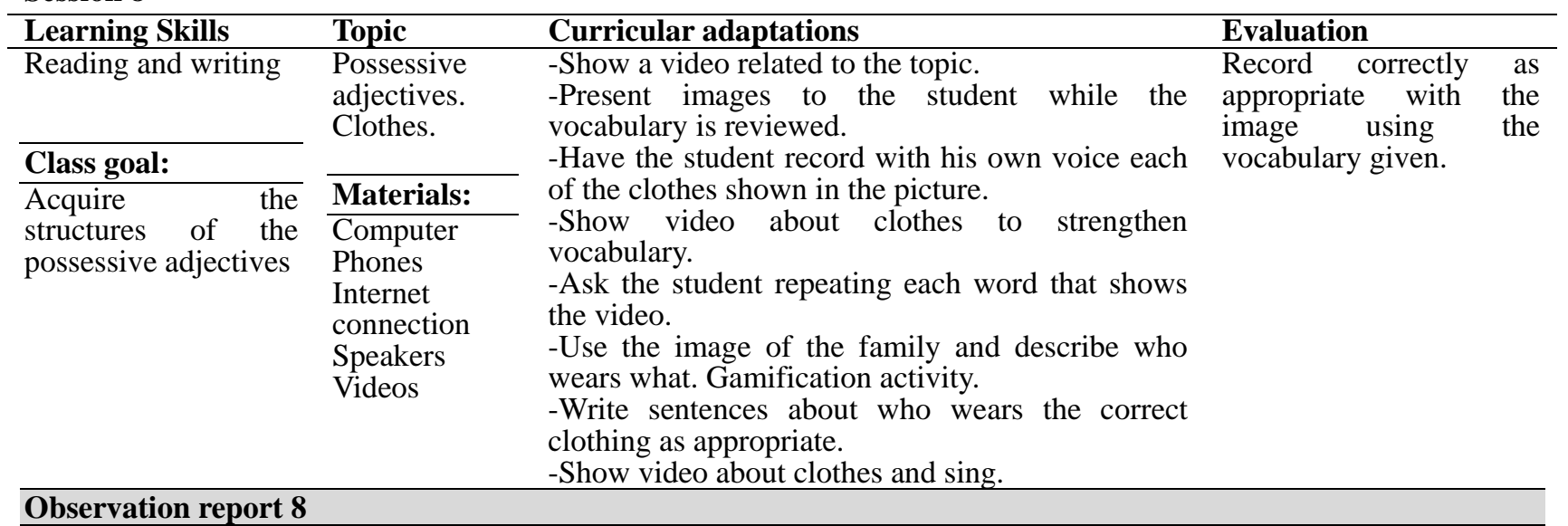

\section{Learner achievement: To understand simple, clear and articulated language slowly.}

To find difference which personal pronoun belongs to the possessive adjective and relating it to the clothes. Auditive comprehension

Observations: The activities carried out with the use of the vocabulary in which Angel recorde his own voice agreeing with the image. He kept calm and totally focused, wanting to listen to the activity more than once. He Understood every element indicated in the image, relating each character with their dress, for this, the image used was chosen thanks to a previous conversation doing the activity with interest and enthusiasm. 
However, the child could manifest a need of a rest, at any time. So that, periods between 3 to 5 minutes of controlled recess were established between the linguistic practices. The recess consisted of leaving him free time to review the visual audio material already worked, use of toilets, and other diferent activity. Once the recess finished, the child showed a better disposition to be able to perform the activities correctly in a first attempt.

In answer to the question 2: What kind of evaluation can be adapted to work with children with special educational needs in English class? In the table 2 is exposed an example of rubric used in this experience.

Table 2. Rubric for evaluation of English language achievement of Children with attention-deficit

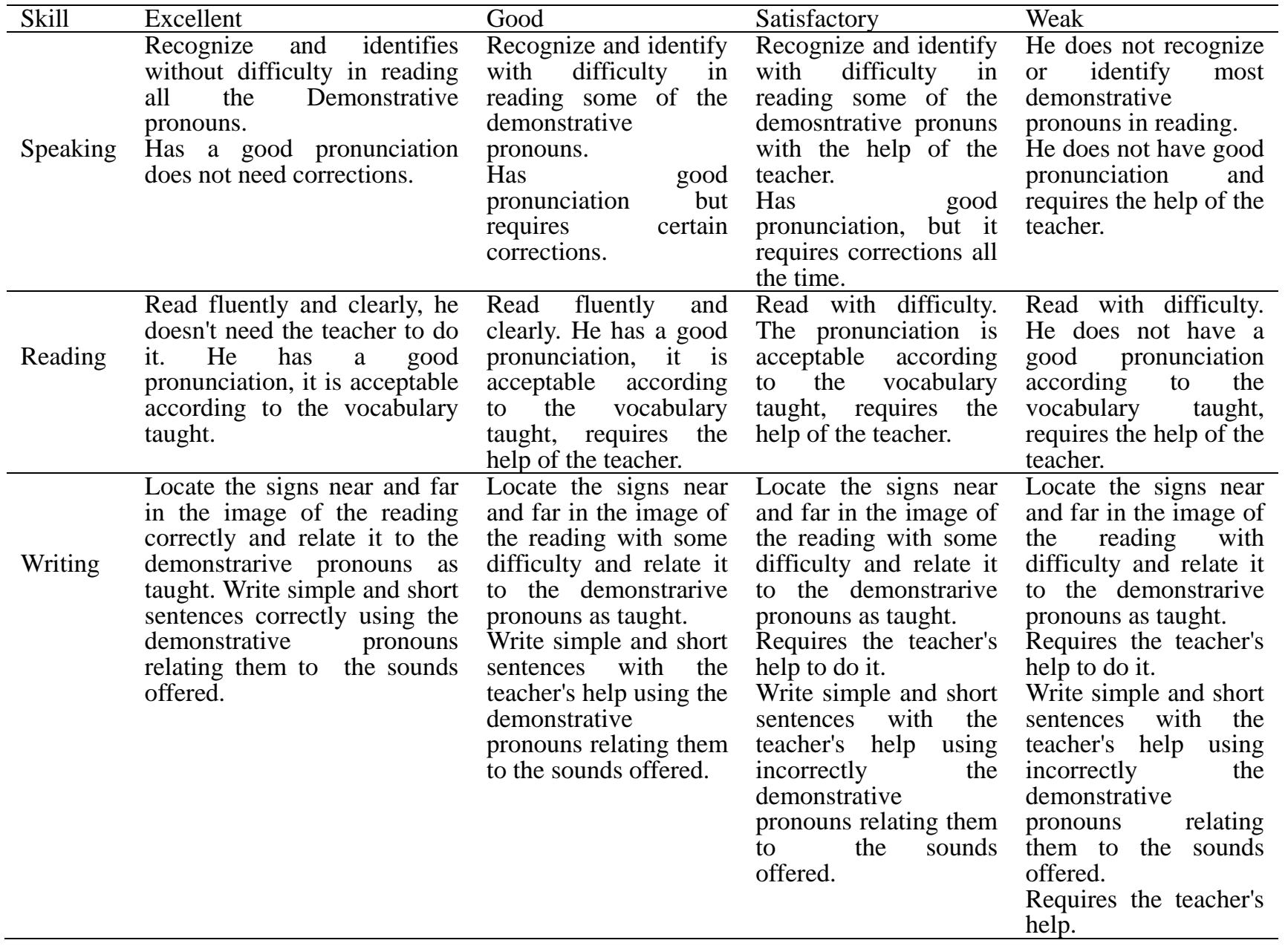

Source: The authors (2019).

As shown in the rubric for evaluation of the participant's English language achievement, it is required to remark that in each activity the Angel was urged to identify and correct his own mistakes, offering time to review the work done.

During the 10 sessions, the child was encouraged to show and repeat the most relevant words and explanations to remember. It should be noted that, for the completion of each session, a brief review of the previous work was initiated; in this way, the reinforcement and the current content were connected. An evaluation was carried out to verify the student learning after each session. Therefore, it was proposed a review of the topic.

To answer the question 3: How was the evolution of the learner's communication skills in English when multimedia means are used in curricular adaptations? See table 3 and figure 1. 
Table 3. Evolution of the learner's communication skills in English

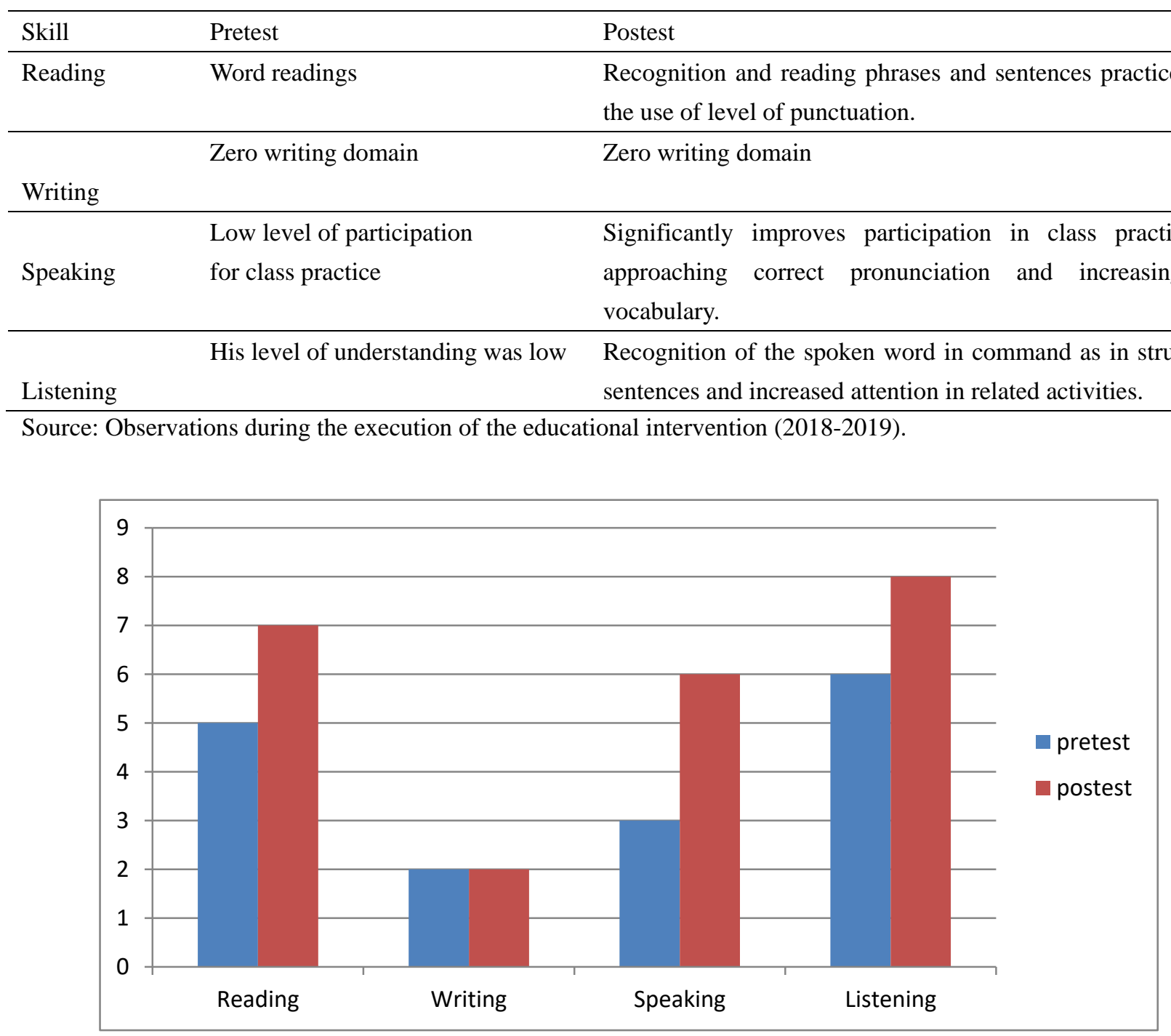

Figure 1. Participant English language skills evolution

The evolution of the learner's communication skills in English shows a satisfactory improvement to the lesson plan designed from the implementation of the relevant curriculum adaptations. It should be noted that although the participant age, he has not been achieved the mastery of the writing skill. The figure 1 presents the results of the pre-test at the beginning of the intervention and the post-test once completed in the curriculum adaptation intervention plan.

\section{Discussion}

This experience teaching English language to a child with attention-deficit ratifies the importance of the technical accompaniment required for teachers to improve the official curriculum adaptations and modifications to the children's capabilities and limitations.

To have a student with special educational needs in class is highly probably in Ecuador; Thus, a teacher should have the disposition and knowledge to support students to reach their learning achievement without any discrimination. Here, the articulation of educational technology and gamification offer innovations for improving the adaptations and modifications required for children to get betteer achievement.

To face the special educational needs is not the responsibility only of student's parents, or the work carried out only for the professionals of the Department of Student Counseling. Educational inclusion is the work of every member of the community. Thus, this study revealed the relevance of interdisciplinary participation in favor of inclusive education. Therefore, it is considered a weakness to conduct this type of research independently of other inherent disciplines. 
Regardless of the terms and definitions reviewed in this research, authors express their agreement to the position of Hall, Vue, Koga, and Silva (2004) when they argue, the most effective way to design adaptations and modifications for the inclusive class, it is to consider every class as an individualized and student-specific process.

Technology is an excellent means to improve the limitations of the traditional classroom, making it inclusive and revolutionary, awakening the motivation of the student with and without special educational needs, and evidencing that face-to-face interaction is not the only communicative channel that guarantees effective learning. Consequently, It is the teacher's mission looking for the means required to allow students to achieve their goals (Chavez et al., 2018; Villafuerte, 2019).

After the review of the Ecuadorian Ministry of Education bibliography, we sustain that persists the requirement of curricular adaptations and modifications for teaching English language to learners with attention-deficit and other educational necessities in Ecuador. This research offers an example of an adaptation process directed to a 4th-grade-student, but it is necessary to designing more adaptations or modifications of the curriculum according to learners' ages, grades, and limitations.

In concern to the child's attention, the following voices of school teachers evidence the child achievements:

B.1.4. "...at the beginning of the classes, the child shows very enthusiastically to work voice recorder"

B.1.7. "...Child attention is greater in each proposed activity using a tablet".

In concern of the linguistic practices, the following voices ratify the contribution of audiovisual to the participant language acquisition process:

B.2.5. "One of the most widely accepted tools used in the application of audiovisual media was the voice recorder" B.2.11. “...Using ICT allowed significant progress in the child's vocabulary acquisition from the previous recording".

B.2.14. "...The child listened to his voice and repeated it. He showed very motivated to practice English using the Audiovisuals"

Those evidences demostrate positive results on the usage of Audiovisuals in the adaptations for English language sessions because, to listen to himself was an activity of great satisfaction that promoted the child interest in achieving the words correct pronunciation.

The unexpected finding is related to the permanent control of the participant's behavior obtained during the English language sessions using ICT. In such a learning environment, emerging conditions that favor the child progress in reading, listening and speaking skills for the fulfilling of the objective.

Every activity proposed by the teacher that is not attractive will produce in the learners total breakdown, surfacing their hyperactivity and inattention (Fernandez et al., 2003) Therefore, it should be possible to teach in such a way that the activity becomes striking, interesting and passionate for every child, transforming them into committed and focused students, achieving the objectives proposed in the curricular adaptation. Some recommendations to considere forn adaptations are:

1. Teachers should teach themes of interest of the learner to motivate and capture their attention.

2. If the activities carried out in classes require a lot of concentration on the part of the student, provide a prudent time to start over another activity.

3. The use of music videos is recommended since they help to internalize the contents taught. Also, learners show pleasure when repeating songs.

4. Recording the learners' voices while singing or reading is beneficial and encourages them to improve their pronunciation.

5. In case of perceiving any discomfort on the part of the learners, offer to perform another activity or a few minutes break. Learners can resume the activity.

6. To carry out games such as the puzzle, teachers need to explain very well the dynamics. Thus, learners may have more concentration in terms of the realization of it.

7. It is important to explain to the learner how to identify and correct their own mistakes for more meaningful learning. Offering time to the learner to review the work done.

8. For the realization of each class, a short review of the previous content is done, in this way the current content is reconnected. To complete all the activities, use images that learners like.

9. The use of audiovisual is recommended when the classes are complex for making it easier for the learner to pay more 
attention.

10. Every session should include an evaluation activity to verify the language acquiring and thus propose other appropriate activities.

It is necessary to expand the coverage of educational research projects that focus on the teaching and learning of elementary and high school students, work with students with disabilities, the use of ICT in rural and suburban reality, in coherence with purposes of the 2017-2021 Digital Educational Agenda of Ecuador, which proposes the availability of teaching and technical support mechanisms for the development of educational innovations that make use of educational technology (Ministerio de Educacion del Ecuador, 2017).

The educational intervention generates relevant changes in teaching, taking the audiovisual media as the connection between the content and the student with special educational needs, favoring the modification of the pattern of behavior such as staying attentive to the activity without the need to take a break, the inclusion in recreational and learning activities; therefore, the strengthening of their identity about the group.

From the respective review and analysis of the literature, the objective was met, allowing the validation of both methodological and theoretical guidelines regarding the case of study. It is worth to mention that from the fulfillment of the objective and analysis of the information it could be established that:

The greatest advance probably was the acquisition of vocabulary. The child responds positively to basic instructions such as daily greetings, answers to short questions, develops his verbal expression, and pronunciation through the use of the recorder.

The experience allows proposing the application of adaptations using audiovisual to other cases that present the same educational requirements and teachers who are encouraged to work with technological resources. Meanwhile, the weakest progress was made in writing skills.

Note: This work is a result of the research project titled: Juegos Recreativos para optimizar el desarrollo del equilibrio motriz y expression oral en español e inglés de niños y niñas de educaciòn basica del canton Manta. Facultad de Ciencias de la Educación of the Universidad Laica Eloy Alfaro de Manabì

Acknowledgment: This work appreciates the collaboration of the participant, his family and the school; for the collaboration in this investigation.

This article authors:

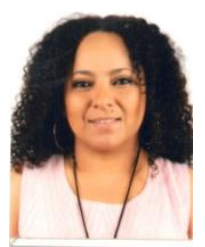

Elena Alonzo Rezabala. She is an Ecuadorian student of the Program Pedagogia de los Idiomas Nacionales y Extranjeros in the Facultad Ciencias de la Educación at the Universidad Laica Eloy Alfaro de Manabí. Ecuador. Her lines of research are English as Second Language, Inclusive education, and Entrepreneurship. She is an active member of the research project: Los juegos recreativos para optimizar el desarrollo del equilibrio de niñas y niños de educación básica 2018-2020. Etapa II: Juegos recreativos para fortalecer el equilibrio y la expresión de niños con síndrome de Down del cantón Manta, Ecuador.

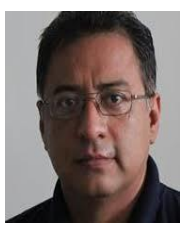

Jhonny Saulo Villafuerte Holguin, PhD. He is an Ecuadorian professor in the Facultad Ciencias de la Educación at the Universidad Laica Eloy Alfaro de Manabí. His lines of research are: Inclusive education and learning environment; Technological education; Sustainable and human development. He had published works about English Language acquisition, environmental education, and entreprership. He is an active member of the research project: Los juegos recreativos para optimizar el desarrollo del equilibrio de niñas y niños de educación básica 2018-2020. Etapa II: Juegos recreativos para fortalecer el equilibrio y la expresión de niños con síndrome de Down del cantón Manta, Ecuador.

\section{References}

Adell, J., \& Castañeda, L. (2010). Los Entornos Personales de Aprendizaje (PLEs): una nueva manera de entender el aprendizaje. En R. Roig Vila y M. Fiorucci (Eds.), Claves para la investigación en innovación y calidad educativas (pp. 19-30). España: Editorial Marfil.

Ahmad, A. (2011). A short description of social networking websites, and its uses. Inter. Journal of Advanced Computer Science and Applications, 2(2), 1-20. https://doi.org/10.14569/IJACSA.2011.020220

Arguello, M. (2013). Guía de Trabajo: Adaptaciones Curriculares para la Educación Especial e Inclusiva. Ministerio de Educacion del Ecuador.

Aviram, A., \& Eshet-alkalai, Y. (2006). Towards a theory of digital literacy: Three scenarios for the next steps. European Journal of Open, Distance and E-Learning, 1(1), 1-10. Retrieved from 
http://www.eurodl.org/materials/contrib/2006/Aharon_Aviram.htm

Barros, C., \& Barros, R. (2015). Los medios audiovisuales y su influencia en la adolescencia desde alternativas de análisis. Revista Universidad y Sociedad [on line], 7(3). 26-31. Retrieved from http://rus.ucf.edu.ec

Bravo, S., Villafuerte, J., Ramírez, X., Luzardo, L., \& Zambrano, T. (2017). Estudiantes con discapacidad física y el acceso a Tecnologías de Información y Comunicación en centros escolares. Retrieved from https://webcache.googleusercontent.com/search?q=cache:YdEJ6cXWgA0J:https://proceedings.ciaiq.org/index.php /ciaiq2017/article/download/1493/1449+\&cd=14\&hl=en\&ct=clnk\&gl=ec

Cabero, J., \& Barroso, J. (2016). Nuevos escenarios digitales, Las tecnologías de la información y la comunicación aplicadas a la formación y desarrollo curricular. Sevilla: Pirámide.

Castaño, C. (2003). El rol del profesor en la transición de la enseñanza presencial al aprendizaje on line. Revista Científica de Comunición y Educación, 21(1), 49-55. Retrieved from https://dialnet.unirioja.es/descarga/articulo/755201.pdf

Chavez, A., Pizarro, J., \& Jimenez, T. (2018). Necesidades educativas especiales y tecnología en la enseñanza-aprendizaje del inglés. Editorial UTmachala. Ecuador. Retrieved from http://repositorio.utmachala.edu.ec/bitstream/48000/14251/1/Cap.2-La\%20tecnolog\%C3\%ADa\%20como\%20apoy o\%20para\%20la\%20ense\%C3\%B1anza\%20del\%20ingl\%C3\%A9s\%20en\%20el.pdf

Durall, E., Gros, B., Maina, M., Johnson, L., \& Adams, S. (2012). Perspectivas tecnológicas: educación superior en Iberoamérica 2012-2017, Austin, Texas. The New Media Consortium. Retrieved from http://openaccess.uoc.edu/webapps/o2/bitstream/10609/17021/6/horizon_iberoamerica_2012_ESP.pdf

Esteve, F., Duch, J., \& Gisbert, M. (2014). Los aprendices digitales en la literatura científica, diseño y aplicación de una revisión sistemática entre 2001 y 2010. Revista de medios y Educación Pixel-Bits, 45(1), 9-21. Retrieved from https://idus.us.es/xmlui/bitstream/handle/11441/45732/100-1491-1-PB.pdf?sequence= 1yisAllowed=y

Fernández, J. M., \& Torres, J. A. (2015). Teacher attitudes and best practices with ICT

Faculty Adult Continuing Education in Andalusia. Revista Complutense de educación, 26(1), 33-44. Retrieved from http://revistas.ucm.es/index.php/RCED/article/view/43812 /45930

Garay, V. (2012). Innovación educativa con TIC. Google docs, una herramienta para la construcción social del conocimiento en la formación Inicia Docente. Revista Educación y Tecnología, 1(1), 83-109. Retrieved from: https://dialnet.unirioja.es/descarga/articulo/4169410.pdf

Garay, U., Luján, C., \& Etxebarria, A. (2013). El empleo de herramientas de la Web 2.0 para el desarrollo de estrategias cognitivas: un estudio comparativo. Porta Linguarum, 20(1), 169-186. Retrieved from https://www.ugr.es/ portalin/artículos/PL_numero20/11\%20\%20Urtza.pdf

Garay, U. (2016, Jul, 5). El nuevo rol del docente ante los contextos emergentes de aprendizaje digital. Universidad del País Vasco. [video]. Retrieved from https://www.youtube.com/watch?v=Ci_RUC_JPbw

Fernandez, F., Hinojo, F., \& Aznar, I. (2003). Dificultades del alumnado con trastorno por déficit de atención con hiperactividad (TDAH) en el aula: implicaciones para la formación docente. Enseñanza, 21(1), 219-232. España. Ediciones Universidad de Salamanca.

Hall, T., Vue, G., Koga, N., \& Silva, S. (2004). Curriculum Modification. Wakefield, MA: National Center on Accessing the General Curriculum. (Links updated 2014). Retrieved [insert date] from http://aem.cast.org/about/publications/2004/ncac-curriculum-modification.html

Heath, M., \& Ravitz, J. (2001). Teaching, learning and computing: What Teachers Say. Reporte de la investigación. Presentado en la Conferencia Mundial de Educación Multimedia, Hipermedia y Telecomunicaciones. Finlandia. Retrieved from http://elearnmag.acm.org/featured.cfm?aid=1865476

Hernández, M. J., \& Fuentes, M. (2011). Aprender a informarse en la red: ¿Son los estudiantes eficientes buscando y seleccionado información? Teoría de la Educación. Educación y Cultura en la Sociedad de la Información, 12(1), 47- 79. Retrieved from https://www.redalyc.org/pdf/2010/201021400004.pdf

Hidalgo, M. I., \& Zoutullo, C. (2014). Trastorno por déficit de atención e hiperactividad. Madrid. Retrieved from Www.pediatriaintegral.es

Johnson, L., Adams, S., Gago, D., García, E., \& Martín, S. (2013). NMC Perspectivas Tecnológicas: Educación Superior en América Latina 2013-2018. Un Análisis Regional del Informe Horizon del NMC. Austin, Texas: The New Media Consortium. Retrieved from https://www.nmc.org/pdf/2013-technology-outlook-latin-america-ES.pdf

Klingler, V. (2000). Psicología Cognitiva Estrategias en la práctica docente. Mexico. McGRAW-HILL 
Luzardo, L., Villafuerte, J., Bravo, S., \& Corral, E. (2018). Compromiso o indiferencia: dicotomía ante la presencia de estudiantes con hipoacusia en una comunidad universitaria. En Autores varios: Educar desde la complejidad para la escuela del siglo XX. Pp.145-165. Ecuador. Editorial. ULEAM. Retrieved from http://www.munayi.uleam.edu.ec/wp-content/uploads/2018/11/Educar-desde-la-complejidad-para-la-escuela-del-si glo-xxi-listo.pdf

Medina, J. D. (2010). Introducción a los medios Audiovisuales. TDAH y Educación; Hacia una visión Holística y comprensiva de su evaluación y tratamiento.

Ministerio de Educació del Ecuador, 2017 Agenda Educativa Digital 2017-2021 Quito - Ecuador recuperado. Retrieved from https://educacion.gob.ec/wp-content/uploads/downloads/2017/11/Agenda-Educativa-Digital.pdf

Narvarte, M. (2007). Lectoescritura. Barcelona. Graficas Mármol A.L.

Palazio-Arko, G. (2016). Implementación en clase, autocorrección y conversión a Telegram app de un diccionario de televisión y vídeo. En J. Palazio (Ed.)., Actas del IX Congreso Internacional sobre Educación Abierta y Tecnología. Ikasnabar-GUIDE 2016. Universidad del País Vasco. Retrieved from: https://addi.ehu.es/bitstream/handle/10810/25910/UCPDF164894.pdf?sequence=1\&isAllowed=y

Ricoy, M. C., \& Couto, M. J. (2012). The approach to the professional context as a motive to investigate about ICT: A qualitative study. Revista Complutense de Educación, 23(2), 443-446. Retrieved from https://revistas.ucm.es/index.php/RCED/article/download/40037/38475+ycd=1 yhl=enyct=clnkygl=esycl ient=

Salgado, N. (2017). Propuesta metodológica para el aprendizaje de inglés en la Universidad Tecnológica Equinoccial (Ecuador) con el uso de las TIC. (Tesis doctoral). Universidad de Extremadura. España. Retrieved from https://repositorio.pucese.edu.ec/bitstream/123456789/616/1/QUINONEZ\%20LUQUE\%20JENNY\%20GABRIEL A.pdf

Salinas, M. I. (2011). Entornos virtuales de aprendizaje en la escuela: tipos, modelo didáctico y rol del docente. Semana de la Educación 2011: Pensando la escuela. PROSED y UCA. Retrieved from http://www.uca.edu.ar/uca/common/grupo82/files/educacion-EVA-en-la-escuela_web-Depto.pdf

Sun, P. C., Tsai, R. J., Finger, G., Chen, Y., \& Yeh, D. (2007). What drives a successful e-Learning? An empirical investigation of the critical factors influencing learner satisfaction. Computers y Education, 50(1), 1183-1202. https://doi.org/10.1016/j.compedu.2006.11.007

Valqui, C., González, J. E., Góngora, M., \& Bazán, H. (2015). La educación crítica y los desafíos en el siglo XXI. México: Ediciones y Gráficos Eón, S.A. Recuperado de http://www.rebelion.org/docs/198343.pdf

Villafuerte, J., Luzardo, L., Bravo, S., \& Romero, A. (2017). Implicaciones y Tensiones en Procesos de Inclusión Educativa, Adolescentes con discapacidad física narran sus experiencias. Revista Cumbres, 3(2), 9-16. Retrieved from http:// investigacion.utmachala.edu.ec/revistas/index.php/Cumbres/article/view/240

Villafuerte, J., \& Benítez, R. (2018). Competencias del profesional de la administración y finanzas para una economía basada en el conocimiento. Revista Educación, 42(2), 1-20. https://doi.org/10.15517/revedu.v42i2.27559

Villafuerte, J. (2019). Tecnología de la Información y Comunicación y el desarrollo de la competencia comunicativa en inglés de los futuros docentes de lengua extranjera de Ecuador: propuesta de intervención educativa. Tesis doctoral. Programa de en Psicodidáctica y psicología de la enseñanza y didácticas específicas. Retrieved from https://addi.ehu.es/bitstream/handle/10810/35071/TESIS_VILLAFUERTE_HOLGUIN_JHONNY\%20SAULO.pd $\mathrm{f}$ ? sequence $=1 \&$ isAllowed $=\mathrm{y}$

Zourou, K. (2007). Paradigme(s) émergent(s) autour des apprentissages collectifs médiatisés en langues. ALSIC, 10(2), 1-26. https://doi.org/10.4000/alsic.688

\section{Copyrights}

Copyright for this article is retained by the author(s), with first publication rights granted to the journal.

This is an open-access article distributed under the terms and conditions of the Creative Commons Attribution license which permits unrestricted use, distribution, and reproduction in any medium, provided the original work is properly cited. 